\title{
A redescription of Astyanax gymnodontus (Eigenmann, 1911), new combination, a polymorphic characid fish from the rio Iguaçu basin, Brazil
}

\author{
Carla Simone Pavanelli and Carlos Alexandre Miranda Oliveira
}

Astyanax gymnodontus (Eigenmann, 1911), new combination, a polymorphic characid fish endemic to the Rio Iguaçu basin in Southern Brazil, is redescribed. The species was originally described as belonging to the monotypic genus Psalidodon, distinguished from Astyanax by the possession of a single series of teeth on the premaxilla (vs. two series), by the presence of relatively compressed teeth on the premaxillary and dentary bones (vs. relatively bulky teeth), and by the absence of lips (vs. lips present). Examination of a large number of specimens from the rio Iguaçu basin that present dental and lip features that were intermediate between Psalidodon and Astyanax indicated that specimens attributed to Psalidodon show extreme characters observed within a polymorphic Astyanax species. Accordingly, the genus Psalidodon is synonymized under Astyanax. Specimens of "Astyanax sp. F" morphotype from the rio Iguaçu basin belong to the species Astyanax gymnodontus and display a regular tooth arrangement and morphology, and their lip development is similar to that of other Astyanax species.

Astyanax gymnodontus (Eigenmann, 1911), combinação nova, um peixe caracídeo polimórfico, endêmico da bacia do rio Iguaçu no sul do Brasil, é redescrito. A espécie foi originalmente descrita como pertencente ao gênero monotípico Psalidodon, diagnosticado de Astyanax pela posse de uma única série de dentes no pré-maxilar (vs. duas séries), pela presença de dentes relativamente comprimidos nos ossos pré-maxilar e dentário (vs. dentes relativamente robustos), e pela ausência de lábios (vs. lábios presentes). O exame de um grande número de espécimes da bacia do rio Iguaçu, apresentando características dentárias e labiais intermediárias entre Psalidodon e Astyanax, indicou que espécimes atribuídos a Psalidodon mostram caracteres extremos observados em uma espécie de Astyanax. Assim, o gênero Psalidodon é sinonimizado sob Astyanax. Espécimes do morfótipo “Astyanax sp. F” da bacia do rio Iguaçu pertencem à espécie Astyanax gymnodontus e exibem dentes com arranjo e morfologia regular, bem como lábios com desenvolvimento similar a outras espécies de Astyanax.

Key words: Neotropical region, Synonymy, Buccal polymorphism, Psalidodon.

\section{Introduction}

The rio Iguaçu basin is a large hydrographic basin in Southern Brazil, occupying 70,800 km² (Maack, 1981). Currently 84 fish species are known to occur in the basin (Garavello et al., 1997; Ingenito et al., 2004; Baumgartner et al., 2006). Most of these species are endemic to that basin, especially those belonging to the genus Astyanax Baird \& Girard, 1854 (Garavello et al., 1997; Alcaraz et al., 2009). Intensive collections carried out by the Núcleo de Pesquisas em Limnologia, Ictiologia e Aqüicultura (Nupélia) of the Universidade Estadual de Maringá (UEM), in the lower rio Iguaçu basin over the past 15 years resulted in the collection of thousands of fish specimens. A large proportion of these specimens belong to the genera Astyanax and Psalidodon Eigenmann, 1911.

Baird \& Girard (1854) described Astyanax but provided a poor diagnosis for the genus. Eigenmann $(1917,1921)$ further described diagnostic features for the genus, such as the inner premaxillary teeth row with five denticulate teeth, a naked caudal fin, and a complete lateral line, among others. Currently, Astyanax includes 125 species (Eschmeyer, 2009). Seven Astyanax species in the rio Iguaçu basin are known: $A$. altiparanae Garutti \& Britski, 2000; A. gymnogenys Eigenmann, 1911; A. ita Almirón, Azpelicueta \& Casciotta, 2002; A. jordanensis Alcaraz, Pavanelli \& Bertaco, 2009; A. leonidas Azpelicueta, Casciotta \& Almirón, 2002; A. totae Haluch \& Abilhoa, 2005; A. varzeae Abilhoa \& Duboc, 2007; and several

Núcleo de Pesquisas em Limnologia, Ictiologia e Aqüicultura (Nupélia), Universidade Estadual de Maringá. Av. Colombo, 5790, 87020-900 Maringá, PR, Brazil. carlasp@nupelia.uem.br 
undescribed species. Of these, only A. altiparanae and A. leonidas are considered to be non-endemic (Garavello et al., 1997; Graça \& Pavanelli, 2002; Ingenito et al., 2004; Baumgartner et al., 2006).

Eigenmann (1911) described Psalidodon as a monotypic genus, comprising only Psalidodon gymnodontus from the rio Iguaçu basin. The genus was described as having no lips, and a unique premaxillary row of compressed teeth. Psalidodon gymnodontus is currently considered to be endemic to the rio Iguaçu basin.

In the Nupélia samples, specimens that perfectly fit the original description of $P$. gymnodontus were collected, as well as several Astyanax specimens. The species of these two genera can be separated by their teeth and lips; $P$. gymnodontus presents only one row of premaxillary teeth and no lips, while all Astyanax species possess two rows of premaxillary teeth, with five (rarely four) teeth in the inner row, three or four (rarely two or five) teeth in the outer row, and well developed lips (Garavello et al., 1997). Among specimens attributed to the Astyanax species, several which were temporarily called “Astyanax sp. F” by Sampaio (1988) and Garavello et al. (1997) present very similar overall features when compared with P. gymnodontus, except from their lip/ teeth characters. Nevertheless, many intermediate specimens between these two morphotypes were collected and analyzed as well. Their lips range from being well-developed to being poorly developed or absent. Each of these types of lips can be combined with one or two rows of well-positioned premaxillary teeth, or even with an inner series of two along with one, two, three or four teeth forming poorly defined outer row randomly arranged on one or both sides of the superior jaw. Garavello et al. (1997) arbitrarily categorized intermediate specimens with one single row of premaxillary teeth and both well and poorly developed lips as Psalidodon sp. The similarity in the overall features of the three morphotypes (“Astyanax sp. F”, “Psalidodon sp.”, and “P. gymnodontus”) generated the suspicion that they could belong to a single species with a great buccal polymorphism. The main scope of this study is to test whether all these specimens are different species or whether they belong to a single polymorphic species.

\section{Material and Methods}

Meristic and morphometric data traditionally used in characid systematics were taken from 30 specimens in each of the three morphotypes mentioned above. Trusses composed by 21 measurements were also taken (Fig. 1), as suggested by Strauss \& Bookstein (1982).

Traditional measurements are presented as ratios of standard and head lengths. These measurements, together with trusses, were analyzed using both principal components and canonical discriminant analyses, according to Humphries et al. (1981) and Reis et al. (1990), in order to detect any effective differences between the three morphotypes compared. In the principal components analysis, the first component always has the highest percentage of variation and, if the eigenvectors are all positive, this is interpreted as a consequence of the size differences among specimens, as was the case here. This indicates that each variable contributes differently to the size discrimination. The remaining components are interpreted as being representative of body form, according to Jolicouer \& Mosimann (1960). In the second component, eigenvectors of the variables that contributed to the faint separation between both Psalidodon and the Astyanax morphotypes have the highest modular values indicated in bold in Table 1. For these variables, we calculated ratios against all other measurements in order to establish ratios that could diagnose the morphotypes, but all of the calculated ratios overlapped.

Canonical discriminant analysis maximizes differences between the previously defined morphotypes (Garavello \& Reis, 1988), and in this study suggested several unusual ratios between the measurements. The pairs of variables for the ratios were selected by a Pearson's correlation between canonical variables and used residuals of the regression for each character in the principal components analysis. The ratios suggested by that analysis are shown in Table 2. Analyses treating traditional and truss measurements separately were also performed and resulted in even more overlapping results, and hence are not presented. Both analyses were calculated using $\mathrm{SAS}^{\circledR}$ software and the routine proposed by Reis et al. (1990).

The analyzed fishes are deposited at the Coleção Ictiológica do Nupélia (NUP), Maringá, Paraná State, Brazil. Institutional acronyms follow those described at this website: http://research.calacademy.org/research/ichthyology/ catalog/abtabr.html. Other abbreviations are: COPEL (Companhia Paranaense de Energia), and GERPEL (Grupo de Pesquisas em Recursos Pesqueiros e Limnologia).

Seven specimens were radiographed, and five were cleared and stained for osteological observations following the methods of Taylor \& Van Dyke (1985). In counting the total number of vertebrae, the fused PU1+U1 was considered to be a single bone and the vertebrae incorporated into the Weberian Apparatus were counted as four elements.

\section{Results}

In an attempt to incorporate all the intermediate specimens between traditional Astyanax and Psalidodon into the previous classification of Garavello et al. (1997), we temporarily identified all specimens with one or two teeth in the outer premaxillary row on at least one of the sides of the mouth as "Psalidodon sp." morphotype. This and the other two morphotypes ("Astyanax sp. F" and "P. gymnodontus") were compared herein with the aim of confirming whether they are different or belong to a same species. The principal components analysis indicated that the morphotypes characters totally overlapped, as shown in Fig. 2 and Table 1.

A very tenuous separation between both Psalidodon morphotypes and the "Astyanax sp. F" morphotype is suggested in axis 2 of Fig. 2. The measurements that contributed to this axis were interorbital distance, the distance 


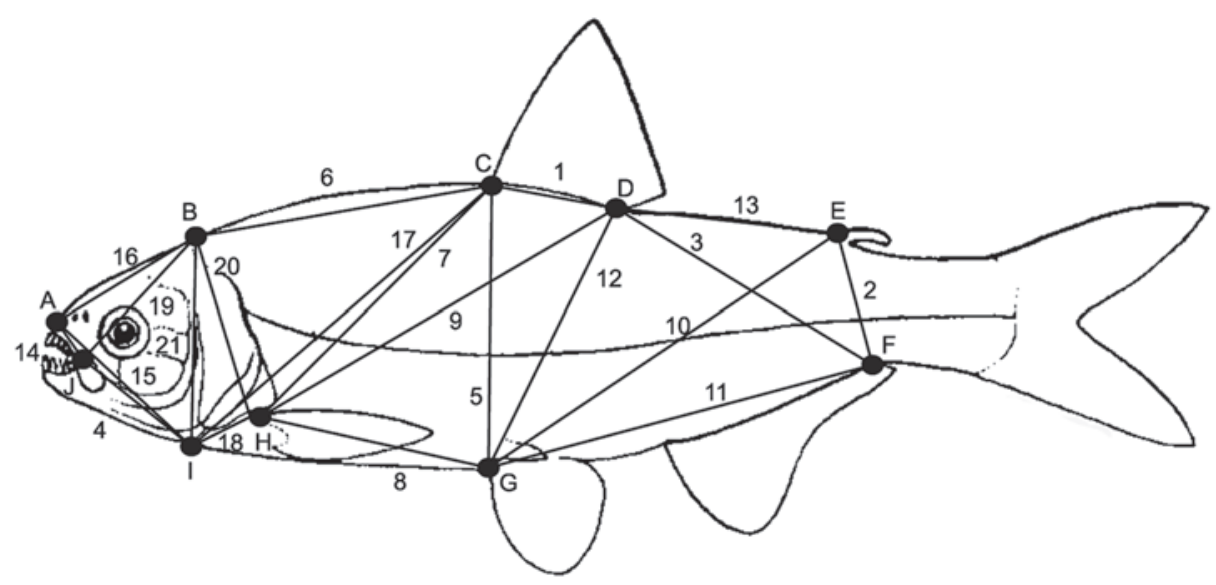

Fig. 1. Landmarks (letters) determined for delimiting trusses, and measurements (numbers) between them (adapted from Fowler, 1948). Descriptions of measurements are provided in Table 1.

Table 1. Variable loadings for the principal component analysis of the three morphotypes of Astyanax gymnodontus. Truss measurements (numbers) are indicated with landmarks (letters) shown according to Fig. 1 . The following abbreviations were used: maxil. comm.: maxillary commissure; supraoc. process: supraoccipital process. The modular higher eigenvectors of principal component 2 are shown in bold (see text for details).

\begin{tabular}{lcc}
\hline \multicolumn{1}{c}{ Measurements } & $\begin{array}{c}\text { Principal } \\
\text { component } 1\end{array}$ & $\begin{array}{c}\text { Principal } \\
\text { component } 2\end{array}$ \\
\hline Traditional & & \\
Standard length & 0.175475 & -0.015037 \\
Body depth & 0.174313 & -0.156548 \\
Caudal-peduncle depth & 0.170235 & -0.073316 \\
Caudal-peduncle length & 0.187413 & -0.020009 \\
Pectoral-fin length & 0.177764 & -0.009366 \\
Pelvic-fin length & 0.154618 & -0.016221 \\
Anal-fin length & 0.136927 & 0.029081 \\
Anal-fin base length & 0.150861 & 0.043254 \\
Dorsal-fin length & 0.151245 & 0.181314 \\
Head length & 0.173240 & $\mathbf{0 . 2 7 3 3 3 5}$ \\
Snout length & 0.169509 & 0.006538 \\
Predorsal length & 0.092302 & 0.161657 \\
Orbital diameter & 0.174891 & 0.235477 \\
Interorbital distance & 0.171353 & $\mathbf{0 . 3 7 3 9 8 6}$ \\
Jaw width & 0.174478 & -0.049973 \\
& & \\
1. Dorsal-fin base length (C-D) & 0.162773 & -0.219392 \\
2. Adipose fin to anal-fin end (E-F) & 0.167340 & -0.219216 \\
3. Dorsal-fin end to anal-fin end (D-F) & 0.171181 & -0.187796 \\
4. Maxillary commissure to isthmus (J-I) & 0.139956 & 0.237986 \\
5. Dorsal fin to pelvic fin (C-G) & 0.173826 & -0.183431 \\
6. Dorsal fin to supraoc. process (C-B) & 0.195386 & -0.130169 \\
7. Dorsal fin to pectoral fin (C-H) & 0.176424 & -0.048835 \\
8. Pectoral fin to pelvic fin (H-G) & 0.189786 & -0.122772 \\
9. Dorsal-fin end to pectoral fin (D-H) & 0.172025 & -0.077577 \\
10. Pelvic fin to adipose fin (G-E) & 0.173087 & -0.191607 \\
11. Pelvic fin to anal-fin end (G-F) & 0.174761 & -0.174482 \\
12. Dorsal-fin end to pelvic fin (D-G) & 0.172729 & -0.185088 \\
13. Dorsal-fin end to adipose fin (D-E) & 0.188709 & -0.230129 \\
14. Snout to maxillary commissure (A-J) & 0.179986 & 0.155008 \\
15. Snout to isthmus (A-I) & 0.142941 & $\mathbf{0 . 2 7 8 7 3 3}$ \\
16. Snout to supraoccipital process (A-B) & 0.144155 & 0.161641 \\
17. Isthmus to dorsal fin (I-C) & 0.180525 & -0.076554 \\
18. Isthmus to pectoral fin (I-H) & 0.168864 & 0.109604 \\
19. Maxil. comm. to supraoc. process (J-B) & 0.144293 & 0.177262 \\
20. Supraoc. process to pectoral fin (B-H) & 0.153166 & 0.149247 \\
21. Isthmus to supraoccipital process (I-B) & 0.154008 & 0.137472 \\
\hline & & \\
\hline
\end{tabular}

between the snout and isthmus, and head length, as shown in Table 1. These metrics had calculated ratios against other measurements presented in Table 2, which also overlapped.

Even when the differences between the previously defined morphotypes were maximized by using the canonical discriminant analysis, all measurements also showed overlapping characters, with only a slight separation observed between both Psalidodon morphotypes and the "Astyanax sp. F” morphotype on axis 1 (Fig. 3).

An extensive list of the most important pairs of variables suggested by this analysis also shows that the ratios of these variables overlapped (Table 2). Meristic data of the morphotypes are presented in Table 3 and show that ranges overlapped except for counts of premaxillary teeth in the outer row, which were previously chosen arbitrarily for separating the intermediary specimens between the traditional Psalidodon and Astyanax.

Based on the meristic analyses, no consistent difference was found between the three morphotypes analyzed since there were overlaps of all data, except for the premaxillary

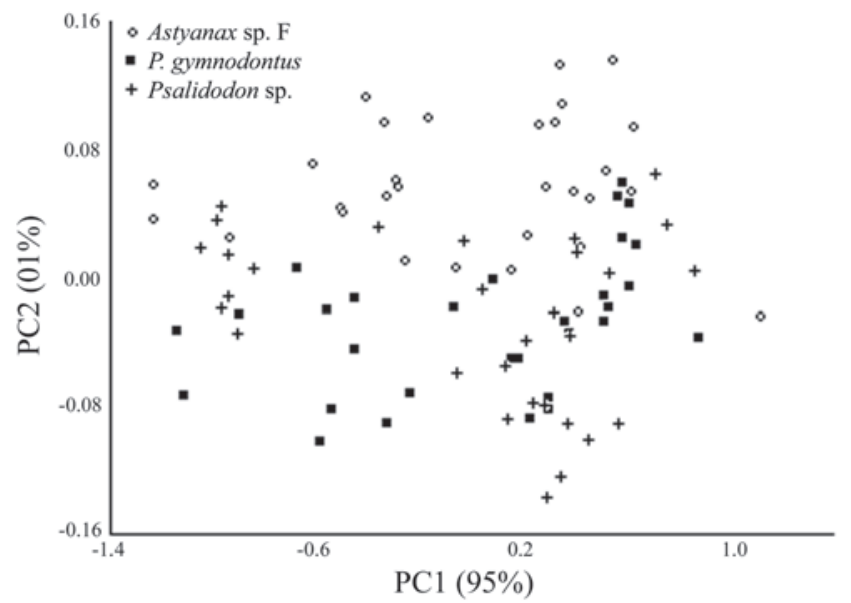

Fig. 2. Plots of scores obtained by principal components analysis of all measurements from the three morphotypes. 
Table 2. The ranges of standard length (SL) and ratios suggested by canonical discriminant analysis are shown for the three morphotypes of Astyanax gymnodontus. Abbreviations of truss measurements are shown according to Table 1, and traditional measurements are: BOD, body depth; CPD, caudal-peduncle depth; CPL, caudal-peduncle length; DFL, dorsal-fin length; HL, head length; IOD, interorbital distance; JW, jaw width; OD, orbital diameter; PDL, predorsal length; and SNL, snout length. Bolded ratios correspond to those responsible for a faint separation between morphotypes in axis 2 of the principal components analysis shown in Fig. 2.

\begin{tabular}{|c|c|c|c|c|c|c|c|c|c|c|c|c|c|c|c|c|c|c|c|}
\hline \multirow[t]{2}{*}{ Morphotypes } & \multicolumn{3}{|c|}{ "P. gymnodontus" } & \multicolumn{3}{|c|}{ "Psalidodon sp." } & \multicolumn{3}{|c|}{ “Astyanax sp. F” } & \multirow{2}{*}{$\begin{array}{l}\text { Morphotypes } \\
\text { Ratios } \\
\end{array}$} & \multicolumn{3}{|c|}{ "P. gymnodontus" } & \multicolumn{3}{|c|}{ "Psalidodon sp." } & \multicolumn{3}{|c|}{ "Astyanax sp. F" } \\
\hline & Low & High & Mean & Low & High & Mean & Low & High & Mean & & Low & High & Mean & Low & High & Mean & Low & High & Mean \\
\hline Ratios/SL range & 56.1 & 123.4 & 91.5 & 58.0 & 122.2 & 89.4 & 52.0 & 136.8 & 89.7 & D-F/A-I & 1.72 & 2.30 & 2.02 & 1.75 & 2.42 & 2.00 & 1.59 & 2.10 & 1.78 \\
\hline SL/CPL & 9.95 & 12.05 & 10.72 & 10.34 & 12.56 & 11.26 & 10.07 & 12.27 & 10.92 & D-F/J-I & 2.13 & 2.94 & 2.52 & 2.22 & 2.86 & 2.48 & 1.85 & 2.82 & 2.22 \\
\hline BOD/C-G & 0.97 & 1.13 & 1.03 & 0.92 & 1.14 & 1.03 & 0.98 & 1.10 & 1.03 & G-E/G-F & 1.00 & 1.17 & 1.11 & 1.05 & 1.21 & 1.12 & 1.03 & 1.22 & 1.11 \\
\hline BOD/D-G & 0.96 & 1.08 & 1.03 & 0.96 & 1.12 & 1.02 & 0.97 & 1.12 & 1.03 & G-E/E-F & 2.89 & 3.52 & 3.15 & 2.99 & 3.78 & 3.22 & 2.80 & 3.53 & 3.16 \\
\hline BOD/E-F & 2.16 & 2.61 & 2.39 & 2.21 & 2.71 & 2.41 & 2.21 & 2.60 & 2.43 & G-E/A-J & 7.24 & 10.14 & 8.42 & 7.45 & 9.41 & 8.42 & 6.67 & 8.67 & 7.83 \\
\hline HL/H-G & 0.85 & 1.15 & 0.98 & 0.87 & 1.25 & 1.02 & 0.87 & 1.30 & 1.04 & G-E/A-I & 2.52 & 3.35 & 2.88 & 2.50 & 3.39 & 2.84 & 2.13 & 2.99 & 2.55 \\
\hline HL/J-B & 0.99 & 1.09 & 1.03 & 0.89 & 1.16 & 1.05 & 0.94 & 1.17 & 1.04 & G-E/B-I & 1.74 & 2.03 & 1.88 & 1.62 & 2.21 & 1.89 & 1.51 & 1.94 & 1.76 \\
\hline HL/D-E & 0.82 & 1.07 & 0.98 & 0.81 & 1.22 & 1.03 & 0.92 & 1.36 & 1.08 & G-E/BOD & 1.19 & 1.43 & 1.32 & 1.24 & 1.44 & 1.33 & 1.20 & 1.40 & 1.30 \\
\hline C-B/SNL & 3.25 & 4.77 & 3.98 & 3.37 & 4.97 & 4.15 & 3.16 & 5.09 & 3.90 & G-E/DFL & 1.77 & 2.30 & 2.03 & 1.80 & 2.23 & 1.98 & 1.51 & 2.24 & 1.90 \\
\hline C-B/IOD & 2.65 & 3.77 & 3.24 & 3.02 & 3.99 & 3.34 & 2.50 & 3.58 & 3.05 & G-E/ OD & 4.41 & 6.92 & 5.54 & 3.88 & 6.23 & 5.35 & 4.02 & 7.02 & 5.05 \\
\hline C-B/J-B & 0.92 & 1.25 & 1.08 & 0.83 & 1.42 & 1.14 & 0.81 & 1.26 & 1.06 & G-E/D-E & 1.66 & 2.11 & 1.90 & 1.66 & 2.24 & 1.95 & 1.73 & 2.21 & 1.92 \\
\hline PDL/G-E & 0.95 & 1.14 & 1.05 & 0.99 & 1.15 & 1.07 & 1.00 & 1.20 & 1.11 & G-E/D-G & 1.24 & 1.49 & 1.36 & 1.27 & 1.50 & 1.36 & 1.22 & 1.47 & 1.34 \\
\hline PDL/C-G & 1.31 & 1.62 & 1.44 & 1.32 & 1.63 & 1.47 & 1.33 & 1.71 & 1.49 & G-E/D-F & 1.30 & 1.53 & 1.43 & 1.29 & 1.52 & 1.42 & 1.29 & 1.57 & 1.43 \\
\hline PDL/G-F & 1.08 & 1.27 & 1.17 & 1.07 & 1.28 & 1.19 & 1.12 & 1.40 & 1.23 & G-E/C-G & 1.24 & 1.48 & 1.36 & 1.23 & 1.49 & 1.38 & 1.23 & 1.52 & 1.34 \\
\hline PDL/E-F & 3.02 & 3.84 & 3.32 & 3.02 & 3.93 & 3.43 & 3.29 & 3.80 & 3.50 & G-E/ IOD & 5.41 & 6.41 & 5.94 & 4.94 & 6.98 & 5.88 & 4.84 & 6.01 & 5.32 \\
\hline E-F/CPD & 1.22 & 1.45 & 1.32 & 1.18 & 1.42 & 1.31 & 1.18 & 1.38 & 1.28 & G-E/C-D & 3.27 & 4.00 & 3.66 & 3.27 & 4.07 & 3.64 & 3.23 & 4.09 & 3.54 \\
\hline E-F/IOD & 1.60 & 2.10 & 1.89 & 1.47 & 2.12 & 1.83 & 1.50 & 1.88 & 1.68 & G-F/A-I & 2.21 & 2.93 & 2.59 & 2.24 & 3.06 & 2.54 & 1.97 & 2.68 & 2.30 \\
\hline E-F/OD & 1.38 & 2.11 & 1.76 & 1.16 & 2.01 & 1.67 & 1.28 & 2.14 & 1.59 & G-F/D-F & 1.18 & 1.42 & 1.28 & 1.16 & 1.44 & 1.27 & 1.21 & 1.46 & 1.29 \\
\hline A-I/IOD & 1.73 & 2.37 & 2.07 & 1.69 & 2.33 & 2.08 & 1.83 & 2.41 & 2.10 & G-F/ IOD & 4.90 & 6.08 & 5.34 & 4.52 & 6.49 & 5.26 & 4.14 & 5.54 & 4.81 \\
\hline A-I/OD & 1.58 & 2.25 & 1.93 & 1.49 & 2.22 & 1.88 & 1.72 & 2.36 & 1.98 & G-F/ DFL & 1.60 & 2.01 & 1.83 & 1.61 & 2.07 & 1.77 & 1.42 & 2.09 & 1.72 \\
\hline H-G/JW & 2.66 & 3.36 & 3.04 & 2.55 & 3.67 & 3.10 & 2.40 & 3.41 & 2.80 & G-F/ OD & 3.98 & 6.05 & 4.98 & 3.48 & 5.59 & 4.79 & 3.70 & 6.31 & 4.56 \\
\hline H-G/DFL & 0.88 & 1.28 & 1.08 & 0.85 & 1.21 & 1.02 & 0.77 & 1.22 & 1.03 & G-F/C-D & 2.80 & 3.74 & 3.29 & 2.93 & 3.55 & 3.26 & 2.78 & 3.77 & 3.20 \\
\hline C-H/D-G & 0.99 & 1.18 & 1.06 & 1.02 & 1.17 & 1.07 & 0.99 & 1.18 & 1.10 & I-H/SNL & 1.40 & 2.02 & 1.65 & 1.38 & 1.97 & 1.68 & 1.41 & 2.05 & 1.68 \\
\hline C-H/C-G & 1.00 & 1.17 & 1.06 & 1.00 & 1.21 & 1.08 & 1.03 & 1.22 & 1.10 & $\mathrm{~J}-\mathrm{B} / \mathrm{I}-\mathrm{B}$ & 0.91 & 1.00 & 0.94 & 0.83 & 1.02 & 0.95 & 0.89 & 1.00 & 0.95 \\
\hline C-G/D-G & 0.92 & 1.03 & 1.00 & 0.89 & 1.09 & 0.99 & 0.92 & 1.09 & 1.00 & $\mathrm{~J}-\mathrm{B} / \mathrm{E}-\mathrm{F}$ & 1.40 & 1.83 & 1.58 & 1.35 & 2.29 & 1.62 & 1.51 & 1.94 & 1.72 \\
\hline C-G/E-F & 2.11 & 2.51 & 2.31 & 2.11 & 2.66 & 2.34 & 2.09 & 2.57 & 2.36 & B-H/I-B & 0.88 & 1.07 & 0.93 & 0.87 & 1.08 & 0.95 & 0.89 & 0.99 & 0.95 \\
\hline C-G/A-J & 4.90 & 7.43 & 6.18 & 5.26 & 7.11 & 6.13 & 5.03 & 6.83 & 5.84 & B-H/E-F & 1.43 & 1.79 & 1.57 & 1.40 & 2.41 & 1.63 & 1.56 & 1.90 & 1.71 \\
\hline C-G/A-I & 1.80 & 2.53 & 2.11 & 1.73 & 2.49 & 2.07 & 1.65 & 2.28 & 1.90 & B-H/CPD & 1.86 & 2.38 & 2.07 & 1.85 & 3.17 & 2.14 & 1.99 & 2.54 & 2.18 \\
\hline C-G/DFL & 1.29 & 1.74 & 1.49 & 1.29 & 1.69 & 1.44 & 1.15 & 1.68 & 1.42 & I-B/ CPD & 1.98 & 2.41 & 2.21 & 1.89 & 2.94 & 2.24 & 2.13 & 2.74 & 2.30 \\
\hline$A-B / C-D$ & 1.68 & 2.13 & 1.91 & 1.61 & 2.20 & 1.89 & 1.70 & 2.60 & 1.97 & I-B/ DFL & 0.95 & 1.19 & 1.08 & 0.91 & 1.16 & 1.05 & 0.98 & 1.20 & 1.08 \\
\hline D-G/E-F & 2.05 & 2.53 & 2.32 & 2.11 & 2.74 & 2.36 & 2.17 & 2.59 & 2.37 & I-B/ IOD & 2.92 & 3.56 & 3.16 & 2.65 & 3.64 & 3.11 & 2.78 & 3.43 & 3.04 \\
\hline D-G/A-J & 4.86 & 7.46 & 6.21 & 5.22 & 7.04 & 6.19 & 5.03 & 6.86 & 5.87 & I-B/D-E & 0.86 & 1.13 & 1.01 & 0.84 & 1.29 & 1.04 & 0.92 & 1.36 & 1.10 \\
\hline D-G/A-I & 1.78 & 2.49 & 2.12 & 1.73 & 2.49 & 2.09 & 1.64 & 2.35 & 1.91 & I-B/E-F & 1.50 & 1.85 & 1.68 & 1.44 & 2.23 & 1.71 & 1.63 & 2.08 & 1.81 \\
\hline D-G/A-B & 1.26 & 1.60 & 1.41 & 1.18 & 1.72 & 1.42 & 1.15 & 1.61 & 1.35 & I-B/C-B & 0.85 & 1.16 & 0.98 & 0.78 & 1.18 & 0.94 & 0.86 & 1.26 & 1.00 \\
\hline D-G/DFL & 1.26 & 1.71 & 1.50 & 1.29 & 1.67 & 1.46 & 1.20 & 1.76 & 1.42 & D-E/A-I & 1.32 & 1.77 & 1.52 & 1.16 & 1.80 & 1.46 & 1.13 & 1.69 & 1.34 \\
\hline D-G/OD & 3.27 & 5.15 & 4.08 & 2.93 & 4.83 & 3.94 & 3.07 & 5.15 & 3.78 & D-E/B-H & 0.88 & 1.26 & 1.06 & 0.72 & 1.28 & 1.03 & 0.83 & 1.15 & 0.97 \\
\hline D-F/D-E & 1.17 & 1.47 & 1.33 & 1.19 & 1.59 & 1.37 & 1.20 & 1.48 & 1.34 & D-E/ OD & 2.25 & 3.61 & 2.93 & 2.01 & 3.49 & 2.77 & 1.95 & 3.76 & 2.64 \\
\hline D-F/ OD & 3.03 & 4.54 & 3.88 & 2.93 & 4.75 & 3.76 & 2.90 & 4.89 & 3.53 & D-E/IOD & 2.77 & 3.58 & 3.13 & 2.52 & 4.05 & 3.03 & 2.40 & 3.23 & 2.79 \\
\hline
\end{tabular}

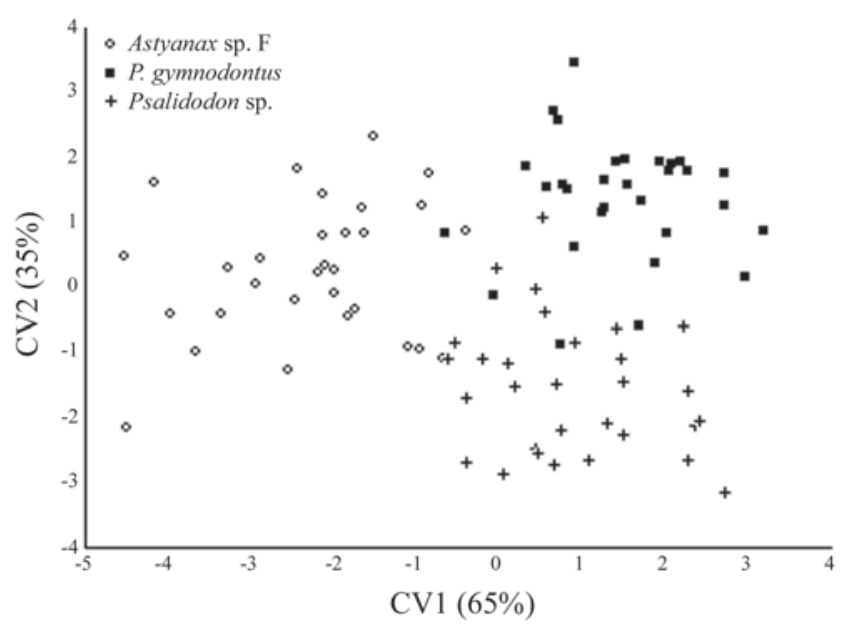

Fig. 3. Plots of scores obtained by canonical discriminant analysis of all measurements from the three morphotypes. teeth of the outer row. In addition, despite some different averages, all the calculated ratios were similar among the morphotypes, including those suggested by the principal components and canonical discriminant analyses. Based on these data, the three morphotypes are herein considered to belong to the same species, which presents a high buccal polymorphism that had not been described previously for Astyanax species. Accordingly, the dental and soft buccal tissue characters that were thought to be unique to Psalidodon are rather the extreme end of the variation observed within a polymorphic species that was otherwise not distinguishable from species currently assigned to the genus Astyanax, and a new nomenclatural combination, Astyanax gymnodontus, is proposed herein. The genus Psalidodon is considered to be a junior synonym of Astyanax, the oldest genus, and a redescription of the species is provided below. 
Table 3. Counts from 30 specimens of the 3 morphotypes of Astyanax gymnodontus, with the arbitrary difference in the premaxillary teeth of the outer row shown in bold.

\begin{tabular}{lccccccccc}
\hline \multicolumn{1}{c}{ Morphotypes } & \multicolumn{1}{c}{ "Psalidodon gymnodontus" } & \multicolumn{3}{c}{ "Psalidodon sp." } & \multicolumn{3}{c}{ "Astyanax sp. F" } \\
\multicolumn{1}{c}{ Counts } & Low & High & Mean & Low & High & Mean & Low & High & Mean \\
\hline Dentary teeth cusp & 5.00 & 5.00 & 5.00 & 5.00 & 5.00 & 5.00 & 5.00 & 5.00 & 5.00 \\
Premaxillary teeth cusps of inner row & 5.00 & 5.00 & 5.00 & 5.00 & 5.00 & 5.00 & 5.00 & 5.00 & 5.00 \\
Premaxillary teeth cusps of outer row & -- & -- & -- & 3.00 & 3.00 & 3.00 & 3.00 & 3.00 & 3.00 \\
Larger dentary teeth & 5.00 & 7.00 & 5.90 & 5.00 & 6.00 & 5.37 & 5.00 & 6.00 & 5.60 \\
Smaller dentary teeth & 5.00 & 7.00 & 6.00 & 4.00 & 7.00 & 5.63 & 4.00 & 7.00 & 5.70 \\
Maxillary teeth & 1.00 & 4.00 & 2.70 & 1.00 & 4.00 & 2.57 & 2.00 & 4.00 & 2.90 \\
Premaxillary teeth of inner row & 5.00 & 7.00 & 6.07 & 5.00 & 6.00 & 5.27 & 4.00 & 6.00 & 5.07 \\
Premaxillary teeth of outer row & $\mathbf{0 . 0 0}$ & $\mathbf{0 . 0 0}$ & $\mathbf{0 . 0 0}$ & $\mathbf{1 . 0 0}$ & $\mathbf{2 . 0 0}$ & $\mathbf{1 . 6 7}$ & $\mathbf{3 . 0 0}$ & $\mathbf{4 . 0 0}$ & $\mathbf{3 . 6 0}$ \\
Circumpeduncular scales & 13.00 & 16.00 & 14.70 & 13.00 & 16.00 & 14.33 & 14.00 & 15.00 & 14.30 \\
Perforated lateral-line scales & 37.00 & 41.00 & 38.77 & 37.00 & 41.00 & 39.13 & 38.00 & 40.00 & 38.93 \\
Scales between dorsal and adipose fins & 11.00 & 14.00 & 12.57 & 10.00 & 15.00 & 12.07 & 11.00 & 13.00 & 11.93 \\
Post-adipose-fin scales & 6.00 & 9.00 & 6.90 & 6.00 & 8.00 & 6.70 & 7.00 & 9.00 & 7.60 \\
Post-anus scales & 1.00 & 2.00 & 1.80 & 1.00 & 2.00 & 1.53 & 1.00 & 2.00 & 1.50 \\
Pre-anus scales & 23.00 & 25.00 & 24.03 & 23.00 & 25.00 & 24.10 & 23.00 & 25.00 & 24.47 \\
Predorsal scales & 12.00 & 15.00 & 13.60 & 12.00 & 15.00 & 13.97 & 12.00 & 14.00 & 12.83 \\
Rows of scales below lateral line & 5.00 & 6.00 & 5.33 & 5.00 & 6.00 & 5.50 & 5.00 & 6.00 & 5.50 \\
Rows of scales above lateral line & 6.00 & 8.00 & 6.67 & 6.00 & 8.00 & 6.63 & 6.00 & 8.00 & 6.70 \\
Total anal-fin rays & 22.00 & 25.00 & 23.40 & 22.00 & 25.00 & 23.57 & 21.00 & 25.00 & 23.07 \\
Total dorsal-fin rays & 10.00 & 13.00 & 11.50 & 10.00 & 12.00 & 11.43 & 11.00 & 13.00 & 11.60 \\
Total pectoral-fin rays & 12.00 & 15.00 & 13.63 & 12.00 & 15.00 & 13.70 & 12.00 & 14.00 & 13.10 \\
Total pelvic-fin rays & 8.00 & 9.00 & 8.47 & 8.00 & 9.00 & 8.57 & 8.00 & 9.00 & 8.57 \\
\hline
\end{tabular}

\section{Astyanax gymnodontus (Eigenmann, 1911), new combination \\ Figs. 4-5}

Psalidodon gymnodontus Eigenmann, 1911: 166 (original description; type-locality: Porto União, rio Iguaçu; illustration; holotype FMNH 54574, ex CM 3204). Eigenmann \& Myers, 1929: 455 (reproduction of the original description; illustration). -Fowler, 1948: 162 (checklist of Brazilian freshwater fishes). -Géry, 1977: 578 (comparison with Henochilus wheatlandi; referred to the Cheirodontinae; partial illustration). -Severi \& Cordeiro, 1994: 41 (translation of the original description; rio Iguaçu; illustration). -Garavello et al., 1997: 74 (redescription; Segredo Reservoir). -Malabarba, 1998: 230 (type-species of Psalidodon). -Lima et al., 2003: 154 (checklist of South and Central American fishes).

Astyanax sp. F. -Sampaio, 1988: 70 (description; rio Iguaçu; illustration). -Severi \& Cordeiro, 1994: 29 (description; rio Iguaçu; illustration). -Garavello et al., 1997: 73 (description; Segredo Reservoir). -Haluch \& Abilhoa, 2005: 386 (comparison with Astyanax totae). -Abilhoa \& Duboc, 2007: 49 (comparison with Astyanax varzeae).

Psalidodon sp. -Garavello et al., 1997: 74 (description; Segredo Reservoir).

Diagnosis. Astyanax gymnodontus can be distinguished from all other congeners at the rio Iguaçu basin except for $A$. varzeae by the combination of the following characters: thirdinfraorbital margin separated from preopercle by broad skin area as wide as $1 / 5$ to $1 / 3$ of its depth (vs. adjacent or separated by a narrower skin area); teeth with a cutting edge forming a straight line or a convex arc in frontal view (vs. concave arc); premaxillary teeth with five (rarely seven) cusps, with the median being the largest and the other cusps abruptly decreasing in size to the sides ( $v s$. commonly seven, rarely four, five or nine cusps, gradually decreasing laterally); transversally located black humeral blotch ( $v s$. longitudinally located); 21 to 24 anal-fin rays and 37 to 41 lateral-line scales (vs. 18 to 22 and 34 to 38, respectively, in A. totae); and no hooks on pelvic or anal fins. Astyanax varzeae is the congener most similar to A. gymnodontus in the basin, but the latter can be diagnosed by having a deeper body, 2.4 to 3 times in the SL (vs. 3 or 3.5 in A. varzeae), and a longer snout, 3.2 to 4.7 times in the HL (vs. 4.3 to 6.1).

Description. Body elongated and laterally compressed, body deeper at dorsal-fin origin. Predorsal and prepelvic regions of body rounded transversely. Dorsal profile of snout convex, straight or slightly concave from eye to supraoccipital process. Dorsal profile of body gently convex from supraoccipital process to dorsal-fin end, straight or slightly convex from this point to adipose-fin base, straight or slightly concave from this point to caudal fin. Ventral profile of body convex, between anterior tip of jaw and pelvic-fin origin, straight from this point to anal-fin origin. Dorsal-fin origin slightly forward or at vertical through pelvic-fin origin, its distal margin straight. Pectoral-fin origin at vertical through posterior edge of opercle, its margin rounded, when adpressed, reaching or almost reaching pelvic-fin origin. Pelvic-fin origin at about vertical through dorsal-fin origin, its margin slightly convex, when adpressed not reaching anal-fin origin. Anal-fin origin just behind vertical through end of dorsal-fin base, its distal margin slightly concave. Caudal fin with symmetric lobes, or inferior slightly longer, and scales only at base.

Dorsal-fin rays ii or iii,8 to 10 (mean $=9.4$ ); pectoral-fin rays i,11 to 14 (mean $=12.5$ ); pelvic-fin rays i,7 or 8 (mean $=7.5$ ); anal-fin rays iii,19 to 22 (mean $=20.8)$. Lateral line complete, 


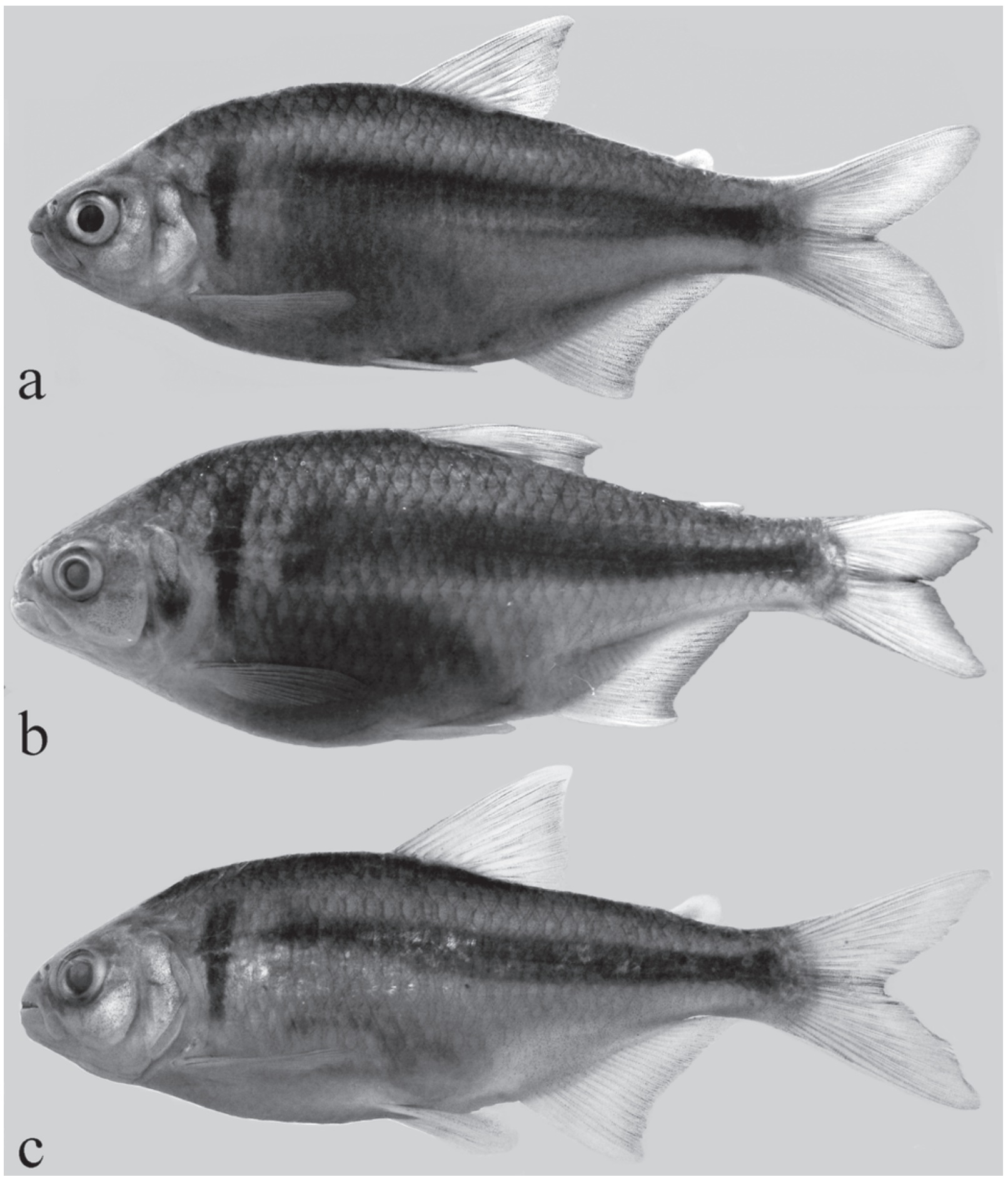

Fig. 4. Astyanax gymnodontus, (a) "Astyanax sp. F” morphotype NUP 4122, 92.3 mm SL, Salto Santiago Reservoir; (b) “Psalidodon sp.” morphotype NUP 3707, 110.6 mm SL, Jordão Reservoir; and (c) “P. gymnodontus” morphotype NUP 4062, 91.0 mm SL, rio Jordão.

with 37 to 41 perforated scales, generally 39 or $40 ; 6$ to 8 rows of scales above lateral line, generally 7 , and 5 or 6 below.

Third-infraorbital margin separated from preopercle by a broad skin area, as wide as $1 / 5$ to $1 / 3$ of its depth. Dentary larger teeth 5 to 7 , with three cusps, in anterior row, and smaller 4 to 7 , generally 5 or 6 in posterior row. Premaxillary teeth 4 to
7 , generally 5 or 6 , with five cusps, in inner row, 1 to 4 with three cusps regular or irregularly arranged in outer row, when present. Outer row commonly not bilaterally symmetric. Maxillary teeth 1 to 4 with three cusps. All teeth with largest median cusp, abruptly decreasing in size up to smallest more laterally placed. Cutting edge of teeth with cusps in a straight 
line or forming a very wide convex arc in frontal view. Lips absent or, when present, ranging from poorly developed to completely covering premaxillary and dentary teeth. Polymorphism in teeth and lips development is shown in Fig. 5.

Color in alcohol. Dorsal region of head and body dusky, gradually lighter towards ventral region. A humeral black spot, occasionally slightly diffuse, transversally elongated, sometimes with faint smaller second humeral dark grey spot. A broad dark grey lateral band present just above lateral line, from opercle to caudal-fin end, over caudal-fin median rays.

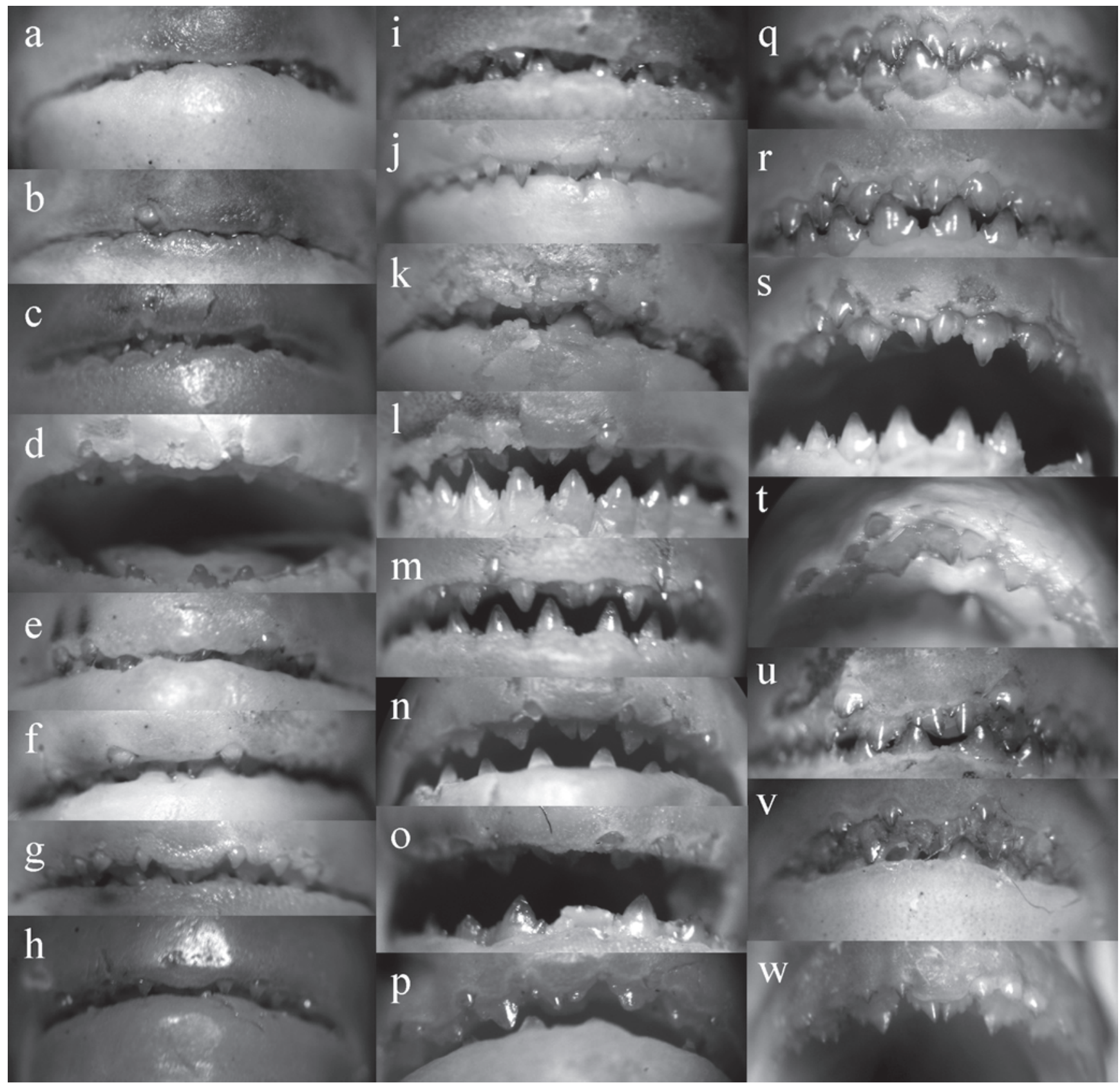

Fig. 5. Some examples of dental and lip polymorphisms displayed by Astyanax gymnodontus, with the number of the lot (all of NUP collection), SL in mm, and the number of premaxillary teeth in the outer row, on the left and right sides (in parentheses). Left column, well-developed lips: (a) 1583, 65.2 (0-0), (b) 4062, 97.1 (1-0), (c) 1653, 64.2 (1-1), (d) 618, 128.5 (1-3), (e) 3766, 97.5, (2-1), (f) 1643, 105.4 (2-3), (g) 3686, 92.2 (4-3), (h) 2719, 99.9 (4-4); middle column, ill-developed lips: (i) 2297, 53.8 (0-1), (j) 1582, 93.2 (0-2), (k) 1582, 85,2 (0-3), (l) 4348, 80.1 (1-1), (m) 2050, 66.2 (1-2), (n) 1579, 72.0 (1-3), (o) 1643, 99.0 (3-3), (p) 635, 65.4 (3-4); right column, lacking lips: (q) 1583, 99.9 (0-0), (r) 3766, 100.2 (1-0), (s) 1583, 98.0 (2-0), (t) 1579, 75.1 (3-0), (u) 3707, 68.0 (1-1), (v) 3037, 97.4(2-2), (w) 1583, 80.4(4-4). 
Sexual dimorphism. Secondary sexual characters were not found in any of the examined specimens.

Distribution. Astyanax gymnodontus is only known to occur in the rio Iguaçu basin in Southern Brazil (Fig. 6).

\section{Discussion}

Eigenmann (1911) described Psalidodon gymnodontus based on three specimens from Porto União, rio Iguaçu basin, which represent the extreme end of the variation displayed by Astyanax gymnodontus. Redescribing $P$. gymnodontus including all morphotypes would not allow an effective differentiation from the Astyanax species, since one of the morphotypes is completely coincident with the features of that genus. Therefore, considering the buccal polymorphism found in that species, we suggest that Psalidodon should be considered to be a junior synonym of Astyanax. Preliminary molecular analyses carried out by A. Prioli (pers. comm.) corroborates that the three morphotypes likely represent a single species, since they are much more similar (within an acceptable range for populations of a same species) than with the remaining Astyanax species from the rio Iguaçu basin.

Polymorphism in trophic structures is still poorly known among teleosts. Smith \& Skúlason (1996) published an extensive revision on resource polymorphism on fishes, amphibians and birds, mentioning several examples in freshwater fishes of North and Central America, Europe and Africa. However, the only case they cited in the Neotropics was the trophic polymorphism that was well described for parodontid trans-Andean genus Saccodon, published by Roberts (1974). In characiforms, aside from Saccodon species, Lucena (2007) described a polymorphism in oral features of some species of the Roeboides species belonging to the $R$. affinis species-group. Astyanax gymnodontus represents the third case of buccal polymorphism in characiforms.

According to Hahn et al. (1997), this species has a relatively broad trophic spectrum at the Segredo Reservoir, composed of vegetal and animal materials. Hahn et al. (1997) also observed the morphotypes "Astyanax sp. F" and "Psalidodon sp.", which possess an outer row of premaxillary teeth, and feed mainly on vegetal materials, while "P. gymnodontus" feeds mainly on terrestrial coleoptera. This suggests that the polymorphism allows that species to explore further feeding habitats (Soulé \& Stewart, 1970). Hence, the buccal polymorphism revealed here is also attributed to trophic factors. The continuous replacing of teeth rows during the life cycle could allow the transformation from one morphotype to another. Actually, a few specimens with a single series of teeth on one side of the premaxilla and two rows on the other side were observed, but not preserved. Nevertheless, no relationship between these transformations and an environmental variable was found by comparing their occurrence with available environmental data. Further studies focusing on trophic anatomy and behavior, as well as environmental experiments examining trophic resource abundance would improve our understanding of this feature.

The rio Iguaçu ichthyofauna is well known for its high endemism and consequently for being very distinct in comparison to the remaining rio Paraná fish fauna because of the very high waterfalls situated upstream from its mouth into the rio Paraná, which is an effective barrier to the dispersal of fish species (Garavello et al., 1997). There are many genera or even families that are widely distributed in the rio Paraná basin, including several large migratory fish species which are absent in the rio Iguaçu basin (Agostinho et al., 1997a). Astyanax is the most diversified fish genus in the rio Iguaçu basin. In addition, Astyanax species are the most abundant fishes in this basin, comprising almost 70\% of fish species in a study carried out in Segredo Reservoir, and almost $80 \%$ of the total fish captured in the Foz do Areia Reservoir (Agostinho et al., 1997b). In this situation, it would be very beneficial ecologically for one congener to enlarge its feeding habitat to avoid competition.
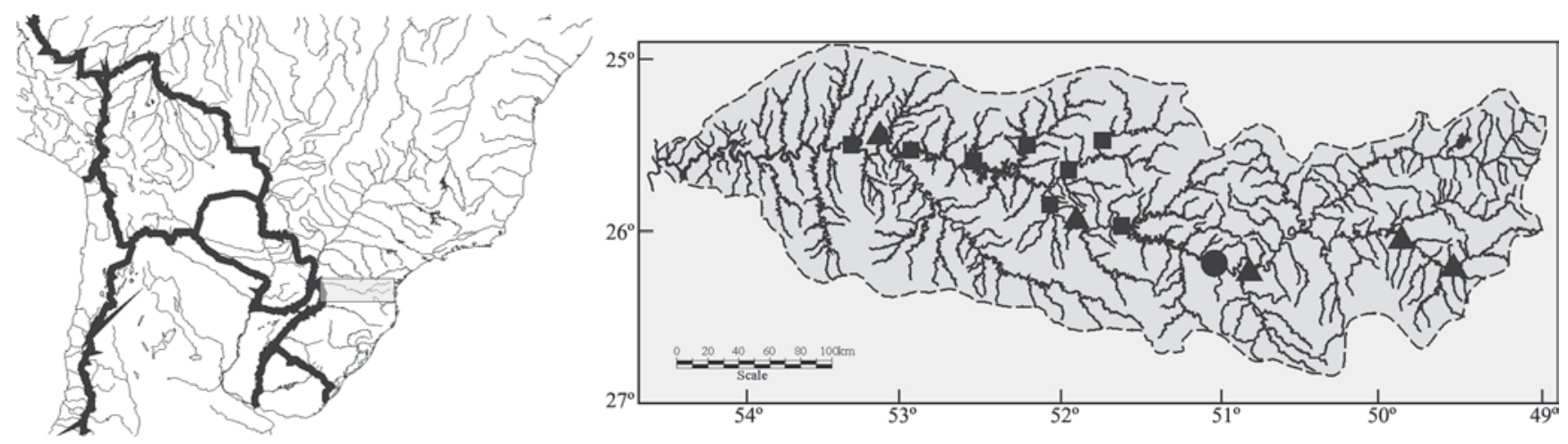

Fig. 6. Map of Southern Brazil and adjoining countries showing the geographic distribution of Astyanax gymnodontus in the rio Iguaçu basin (rectangle in focus). Bold lines are national borders. Squares = examined material; triangles = distribution showed by Severi \& Cordeiro (1994); and dot = type-locality of Psalidodon gymnodontus. Some symbols represent more than one lot or locality. 
Examined material. Split in each former morphotype, all specimens are from the lower rio Iguaçu basin, Paraná, Brazil. “Astyanax sp. F”. - Cavernoso Reservoir (município de Laranjeiras do Sul): NUP 2667 (4, 68.9-78.4), Nov 2001, COPEL. - Caxias Reservoir (município de Capitão Leônidas Marques boundary with Nova Prata do Iguaçu): NUP 1640 (3, 65.9-83.2), Jul 2001, Nupélia; NUP 2460 (7 of 24, 52.0-136.8), 18 Jan 2000, Nupélia. - Jordão Reservoir (município de Candói boundary with Reserva do Iguaçu): NUP 635 (4 of 18, 53.9138.4), Aug 1995 to May 1999, COPEL. - Salto Santiago Reservoir (município de Laranjeiras do Sul boundary with Saudade do Iguaçu): NUP 951 (12 of 18, 97.9-119.9), 08 Jun 2004, GERPEL. "Psalidodon gymnodontus”. - Curucaca Reservoir (município de Guarapuava): NUP 2423 (1 of 4, 53.4-73.7), Jul 2001, COPEL. - Foz do Areia Reservoir (município de Bituruna): NUP 2036 (1, 99.3), Aug 1993 to Dec 2000, Nupélia; NUP 2062 (1, 112.8), 26 Oct 1998, Nupélia. Jordão Reservoir: NUP 616 (8 of 13, 46.4-107.3), Aug 1995 to May 1999, COPEL; NUP 1648 (2 of 4, 64.6-88.3), Aug 1995 to May 1999, Nupélia. - Rio Iguaçu (município de União da Vitória): FMNH 54547, Holotype (189.0), 27 Dec 1908; FMNH 71559, Paratype (145.0), 1909 (in original description date is the same as the holotype). - Salto Santiago Reservoir: NUP 2779 (3 of 4, 61.6-97.4), Jul 2001, COPEL. - Segredo Reservoir (município de Reserva do Iguaçu boundary with Mangueirinha): NUP 1583 (11 of 26, 72.0-125.5), Mar 1993 to Mar 1995, Nupélia; NUP 2296 (2, 73.6-91.7), 1999 to 2000, COPEL; NUP 2297 (1 of 16, 55.8-100.0), 1999 to 2000, COPEL. "Psalidodon sp.”. - Caxias Reservoir: NUP 2050 (4 of 7, 54.8-93.1), Jul 2000, Nupélia. - Curucaca Reservoir: NUP 2422 (2 of 6, 60.5-79.3), Jul 2001, COPEL. -Salto Osório Reservoir (Município de Quedas do Iguaçu): NUP 2787 (2 of 5, 97.7-122.2), Jul 2001, COPEL; NUP 2788 (2, 101.5-107.8), Nupélia. -Salto Santiago Reservoir: NUP 972 (4 of 6, 94.2-119.9), 08 Jun 2004, GERPEL; NUP 2784 (7 of 9, 59.8-101.9), Jul 2001, COPEL. - Segredo Reservoir: NUP 1582 (4 of 17, 53.3-137.5), Mar 1993 to Mar 1995, Nupélia; NUP 1583 (1 of 26,72.0-125.5), Mar 1993 to Mar 1995, Nupélia; NUP 2297 (4 of 16, 55.8-100.0), 1999 to 2000, Nupélia. Additional photographed material. - Jordão Reservoir: NUP 618 (2 of 18), Aug 1995 to May 1999; NUP 635 (2 of 14), Aug 1995 to May 1999; NUP 1643 (3 of 38), Jul 1995 to May 1999; NUP 1653 (1 of 10), Aug 1995 to May 1999; NUP 3686 (1 of 3), Apr 2005; NUP 3707 (2 of 12), 09Apr 2005; NUP 3766 (3 of 62), Apr 2005; NUP 4062 (1 of 3), Apr 2005. - Salto Osório Reservoir: NUP 2719 (1 of 14), Nov 2001; NUP 4348 (1 of 4), Nov 2004. - Salto Santiago Reservoir: NUP 951 (2 of 18), 08 Jun 2004; NUP 4122 (1 of 4), Sep 2005. - Segredo Reservoir: NUP 1579 (5 of 37), Mar 1993 to Mar 1995; NUP 1582 (1 of 18), Mar 1993 to Mar 1995; NUP 1583 (4 of 16), Mar 1993 to Mar 1995; NUP 2065 (2 of 25), 1999 to 2001; NUP 2297(1 of 17), 1999 to 2000.

\section{Acknowledgements}

This paper has benefited from the comments and criticism of Vinícius Bertaco (UFRGS), Luiz Duboc (MHNCI), Mercedes Azpelicueta (MLP), Flávio Lima (MZUSP) and Luiz Gomes (UEM/Nupélia). Thanks are also due to Rodrigo Fernandes and Alessandro Bifi (UEM/Nupélia) for helping with ordination methods, to Mário de Pinna and Cristiano Moreira (MZUSP) for assistance with radiographs, to Weferson da Graça (UEM/ Nupélia) for helping with the photographs, and to Mary Anne Rogers and Philip Willink (FMNH) for examining, photographing, and radiographing types. Nupélia offered logistical support. This study was partially supported by grants from Conselho Nacional de Desenvolvimento Científico e Tecnológico (CNPq) to CSP (Proc. 311975/2006-2).

\section{Literature Cited}

Abilhoa, V. \& L. F. Duboc. 2007. A new species of the freshwater fish genus Astyanax (Ostariophysi: Characidae) from the rio Iguaçu basin, southeastern Brazil. Zootaxa, 1587: 43-52.

Agostinho, A. A., L. M. Bini \& L. C. Gomes. 1997a. Ecologia de comunidades de peixes da área de influência do reservatório de Segredo. Pp. 97-111. In: Agostinho, A. A. \& L. C. Gomes (Eds.). Reservatório de Segredo: bases ecológicas para o manejo. Maringá, Eduem, 387p.

Agostinho, A. A., C. M. L. Ferretti, L. C. Gomes, N. S. Hahn, H. I. Suzuki, R. Fugi \& F. Abujanra. 1997b. Ictiofauna de dois reservatórios do rio Iguaçu em diferentes fases de colonização: Segredo e Foz do Areia. Pp. 275-292. In: Agostinho, A. A. \& L. C. Gomes (Eds.). Reservatório de Segredo: bases ecológicas para o manejo. Maringá, Eduem, 387p.

Alcaraz, H. S. V., C. S. Pavanelli \& V. A. Bertaco. 2009. Astyanax jordanensis (Ostariophysi: Characidae), a new species from the rio Iguaçu basin, Paraná, Brazil. Neotropical Ichthyology, 7(2): 185-190.

Baird, F. S. \& C. Girard. 1854. Descriptions of new species of fishes collected in Texas, New Mexico and Sonora, by Mr. John H. Clark, on the U. S. and Mexican boundary survey, and in Texas by Capt. Stewart Van Vliet, U. S. A. Proceedings of the Academy of Natural Sciences of Philadelphia, 7: 24-29.

Baumgartner D., G. Baumgartner, C. S. Pavanelli, P. R. L. Silva, V. A. Frana, L. C. Oliveira \& M. R. Michelon. 2006. Fish, Salto Osório Reservoir, Iguaçu River basin, Paraná State, Brazil. Check List, 2(1): 1-4.

Eigenmann, C. H. 1911. III. New characins in the collection of the Carnegie Museum. Annals of the Carnegie Museum, 8(1): 164-181.

Eigenmann, C. H. 1917. The American Characidae. Memoirs of the Museum of Comparative Zoology, 43(Part 1): 1-102.

Eigenmann, C. H. 1921. The American Characidae. Memoirs of the Museum of Comparative Zoology, 43(Part 3): 209-310.

Eigenmann, C. H. \& G. S. Myers. 1929. The American Characidae. Memoirs of the Comparative Zoology, 43(Part 5): 429-558.

Eschmeyer, W. 2009. Catalog of fishes. Electronic publication in “World Wide Web”. Availabre from: http://www.calacademy.org/ research/ichthyology/catalog/fishcatmain.asp (April 3, 2009).

Fowler, H. W. 1948. Os peixes de água doce do Brasil. Arquivos de Zoologia do Estado de São Paulo, 6(1 ${ }^{\text {a }}$ entrega): 1-204.

Garavello, J. C, C. S. Pavanelli \& H. I. Suzuki. 1997. Caracterização da ictiofauna do rio Iguaçu. Pp: 61-84. In: Agostinho, A. A. \& L. C. Gomes (Eds.). Reservatório de Segredo: bases ecológicas para o manejo. Maringá, Eduem, 387p.

Garavello, J. C. \& S. F. Reis. 1988. Análise das variáveis canônicas em caracteres quantitativos no gênero Parotocinclus Eigenmann \& Eigenmann, 1889 (Pisces: Loricariidae). Ciência e Cultura, 40(9): 889-891.

Géry, J. 1977. Characoids of the world. Neptune City, T. F. H., 672p. Graça. W. J. \& C. S. Pavanelli. 2002. Astyanax altiparanae Garutti \& Britski, 2000 (Osteichthyes, Characidae) in the Iguaçu River basin. Acta Scientiarum, 24(2): 451-453.

Hahn, N. S., R. Fugi, V. L. L. Almeida, M. R. Russo \& V. E. Loureiro. 1997. Dieta e atividade alimentar de peixes do reservatório de Segredo. Pp. 141-162. In: Agostinho, A. A. \& L. C. Gomes (Eds.). Reservatório de Segredo: bases ecológicas para o manejo. Maringá, Eduem, 387p. 
Haluch, C. F. \& V. Abilhoa. 2005. Astyanax totae, a new characid species (Teleostei: Characidae) from the upper rio Iguaçu basin, southeastern Brazil. Neotropical Ichthyology, 3(3): 383-388.

Humpries, J. M., F. L. Bookstein, B. Chernoff, G. R. Smith, R. L. Elder \& S. G. Poss. 1981. Multivariate discrimination by shape in relation to size. Systematic Zoology, 30: 291-308.

Ingenito, L. F. S., L. F. Duboc \& V. Abilhoa. 2004. Contribuição ao conhecimento da ictiofauna da bacia do alto rio Iguaçu, Paraná, Brasil. Arquivos de Ciências Veterinárias e Zoologia da UNIPAR, 7(1): 23-36.

Jolicouer, P. \& J. E. Mosimann. 1960. Size and shape variation in the painted turtle. A principal component analysis. Growth, 24: 339-354.

Lima, F. C. T., L. R. Malabarba, P. A. Buckup, J. F. Pezzi da Silva, R. P. Vari, A. Harold, R. Benine, O. T. Oyakawa, C. S. Pavanelli, N. A. Menezes, C. A. S. Lucena, M. C. S. L. Malabarba, Z. M. S. Lucena, R. E. Reis, F. Langeani, L. Casatti, V. A. Bertaco, C. Moreira \& P. H. F. Lucinda. 2003. Genera Incertae Sedis in Characidae. Pp. 106-169. In: Reis, R. E., S. O. Kullander \& C. Ferraris Jr. (Eds.). Check list of the freshwater fishes of South and Central America. Porto Alegre, Edipucrs, 729p.

Lucena, C. A. S. 2007. Revisão taxonômica das espécies do gênero Roeboides grupo-affinis (Ostariophysi, Characiformes, Characidae). Iheringia, 97(2): 117-136.

Maack, R. 1981. Geografia física do Estado do Paraná. Rio de Janeiro, J. Olympio, 442p.

Malabarba, L. R. 1998. Monophyly of the Cheirodontinae, characters and major clades (Ostariophysi: Characidae). Pp. 193-233. In: Malabarba, L. R., R. E. Reis, R. P. Vari, Z. M. S. Lucena \& C. A. S. Lucena (Eds.). Phylogeny and classification of Neotropical fishes. Porto Alegre, Edipucrs, 603p.

Reis, S. F., L. M. Pessôa \& R. E. Strauss. 1990. Application of sizefree canonical discriminant analysis to studies of geographic differentiation. Revista Brasileira de Genética, 13(3): 509-520.

Roberts, T. R. 1974. Dental polymorphism and systematics in Saccodon, a neotropical genus of freshwater fishes (Parodontidae, Characoidei). Journal of Zoology, 173(3): 303-321.

Sampaio, F. A. A. 1988. Estudos taxonômicos preliminares dos Characiformes (Teleostei, Ostariophysi) da bacia do rio iguaçu, com comentários sobre o endemismo dessa fauna. Unpublished Ph.D. Dissertation, Universidade Federal de São Carlos, São Carlos, 175p.

Severi, W. \& A. A. M. Cordeiro. 1994. Catálogo de peixes da bacia do rio Iguaçu. Curitiba, IAP/GTZ, 128p.

Smith, T. B. \& S. Skúlason. 1996. Evolutionary significance of resource polymorphisms in fishes, amphibians, and birds. Annual Review of Ecology and Systematics, 27: 111-133.

Soulé, M. \& B. R. Stewart. 1970. The “niche-variation” hypothesis: a test and alternatives. The American Naturalist, 104(935): 85-97.

Strauss, R. E. \& F. L. Bookstein. 1982. The truss: body form reconstructions in morphometrics. Systematic Zoology, 31(2): 113-135.

Taylor, W. R. \& G. C. Van Dyke. 1985. Revised procedures for staining and clearing small fishes and other vertebrates for bone and cartilage study. Cybium, 9(2): 107-119.

Accepted July 24, 2009 Published December 18, 2009 